\title{
Concordance of SMI and CVMS bone maturation indices in pubertal growth stages - cross-sectional study
}

\author{
Concordanţa indicilor de maturare osoasă SMI şi CVMS în etapele creşterii \\ pubertare - studiu transversal
}

\author{
Elena Galan', Andreea Raluca Hlatcu', Angelica Bencze', Elina Teodorescu', Mariana Păcurar², \\ Manuela Chibelean' ${ }^{2}$ Ecaterina Ionescu' \\ ${ }^{1}$ Catedra de Ortodonție și ODF, UMF „Carol Davila“, București, România \\ ${ }^{2}$ Catedra de Ortodonție, UMFST „G.E.Palade“, Tg. Mureş, România
}

\section{ABSTRACT}

In order to verify the concordance of the bone development indices (SMI) estimated on the hand and fist radiograph by the method of Fishman (1982) and the indices of development of the cervical vertebrae (CVMS), estimated on the profile teleradiography by the method of Baccetti (2002), was conducted a cross-sectional study on a group of 150 subjects ( 89 girls and 61 boys), aged $8-18$ years. Based on the existing data in the literature and taking into account the average ages at which the SMI and CVMS stages were reached in the research group, a hypothesis of correspondence between SMI and CVMS stages in the pubertal stages was issued and this hypothesis was statistically verified using the coefficient Cohen $k$. The obtained results $(k=0.82$ for the girls 'group and $k=0.67$ for the boys' group) confirm the concordance of the SMI and CVMS indices within the researched group and validate the correspondence hypothesis issued.

Keywords: cervical vertebrae, bone growth, hand X-ray, puberty, chronological age

\section{REZUMAT}

Pentru a verifica concordanţa indicilor de dezvoltare osoasă (SMI) estimaţi pe radiografia de mână şi pumn prin metoda lui Fishman (1982) şi indicii de dezvoltare a vertebrelor cervicale (CVMS), estimaţi pe teleradiografia de profil prin metodei lui Baccetti (2002), s-a realizat un studiu transversal pe un lot format dintr-un număr de 150 subiecţi ( 89 fete şi 61 băieţi), cu vârste cuprinse între 8 şi 18 ani. Pe baza datelor existente în literatura de specialitate şi ţinând cont de vârstele medii la care au fost atinse stadiile SMI şi CVMS în lotul cercetat, s-a emis o ipoteză de corespondenţă între stadiile SMI şi CVMS în etapele creşterii pubertare şi s-a verificat statistic această ipoteză cu ajutorul coeficientului Cohen $k$. Rezultatele obţinute ( $k=0,82$ pentru lotul fetelor şi $k=0,67$ pentru lotul băieţilor) confirmă concordanţa indicilor SMI şi CVMS în cadrul lotului cercetat şi validează ipoteza de corespondenţă emisă.

Cuvinte cheie: vertebre cervicale, creştere osoasă, radiografia mâinii, pubertate, vârstă cronologică

\section{INTRODUCERE}

Variațiile individuale de creştere, observate la pacienţi având aceeaşi vârstă cronologică, la cele două sexe, în cadrul membrilor aceleiași familii şi chiar la gemenii dizigoţi, au dus la dezvoltarea con- ceptului de vârstă biologică, care definește traseul parcurs până la atingerea maturității individului (1).

Dintre indicatorii vârstei biologice, vârsta osoasă este considerată de majoritatea autorilor ca având cea mai mare acurateţe. Determinarea vâr- 
stei osoase prin analiza radiografiei de mână este o metoda consacrată, existând în literatura de specialitate numeroase studii realizate pe diferite grupe populaţionale care îi atestă valoarea şi aplicabilitatea la scară largă (2-6).

Pe de altă parte, estimarea vârstei osoase prin studiul vertebrelor cervicale este o metodă relativ recentă, comparativ cu folosirea radiografiei de mână şi pumn, care se bazează pe observarea caracteristicilor morfologice ale vertebrelor cervicale în diferite etape de creştere şi dezvoltare a structurilor somatice faciale. Această metodă a câştigat mulţi adepţi, motivul popularităţii sale fiind faptul că interpretarea se realizează pe teleradiografia de profil, investigaţie de rutină din cadrul tratamentului ortodontic, nefiind necesară o expunere suplimentară la radiaţii a pacienţilor $(7,8)$.

În cadrul planificării tratamentului ortodontic, este importantă evaluarea vârstei osoase a pacienţilor, cercetările clinice dovedind eficienţa crescută terapeutică a aparatelor ortodontice aplicate în preajma momentului de maximă creştere pubertară (9-12).

În ceea ce priveşte estimarea vârstei osoase, datele existente în literatura de specialitate confirmă corespondenţa existentă între indicii de dezvoltare a vertebrelor cervicale CVM şi indicii de dezvoltare osoasă SMI (7,8,13-22).

Acest studiu îşi propune să verifice dacă corespondenţa indicilor SMI/CVMS poate fi dovedită şi în cadrul lotului selecţionat de la noi din ţară, ţinând cont de caracterele etnice diferite ale participanţilor la studiu.

Studiile citate în literatură au folosit în general date istorice, existente în bazele de date ale unor instituţii medicale, acestea fiind colectate în prima jumătate a secolului trecut, cu mult timp înaintea publicării lor. În cercetarea actuală, s-au folosit investigaţii recente, marea majoritate a radiografiilor fiind realizate după anul 2012. Ţinând cont de modificările evolutive majore care se înregistrează în fiecare deceniu, în ceea ce priveşte creşterea dezvoltarea, studiul aduce o contribuţie importantă prin actualitatea datelor folosite.

\section{OBIECTIVE}

S-a realizat un studiu transversal pe un lot heterogen, în care s-a urmărit investigarea stadiilor de dezvoltare osoasă (SMI), determinate la copii şi tinerii din lotul de cercetare selectat prin analiza radiografiei de mână pumn prin metoda Fishman (1982) (23) şi determinarea indicilor (CVMS) prin analiza dezvoltării vertebrelor cervicale pe teleradiografia de profil, conform metodei lui Baccetti (2002).

Ulterior, a fost verificată statistic corespondenţa indicilor SMI/CVMS prin raportare la etapele perioadei pubertare.

\section{MATERIAL ŞI METODĂ}

Lotul de studiu a fost selectat din populaţia Bucureştiului şi din zonele limitrofe acestuia, fiind format din 150 pacienţi ( 89 fete şi 61 băieţi), cu vârstele cuprinse între 8 şi 18 ani, subiecţi cu status general echilibrat, fără probleme semnificative de creştere sau hormonale care prezentau anomalii dento-maxilare. Pentru fiecare subiect participant la studiu s-au analizat radiografia de mână şi pumn şi teleradiografia de profil realizate în scop diagnostic, în aceeaşi zi, anterior începerii tratamentului ortodontic.

Radiografiile de mână pumn au fost analizate şi s-au evaluat indicii de dezvoltare osoasă SMI conform metodei lui Fishman (fig. 1, tabel 1). Pe teleradiografiile de profil, s-au evaluat indicii CVMS, $\mathrm{cu}$ ajutorul metodei Baccetti (fig. 2, tabel 2).

Pentru stocarea prelucrarea statistică a datelor, s-a folosit programul Excel din cadrul Microsoft Office Professional plus 2016, la care s-a adăugat pachetul Real Statistics Resource.

A fost verificată repetabilitatea datelor colectate în cadrul studiului cu ajutorul coeficientului Cohen kappa, iar rezultatele obţinute între cele două măsurători realizate succesiv la diferenţă de o lună au arătat un acord perfect sau aproape perfect $(\mathrm{k}=$ $0,984$ şi $\mathrm{k}=0,964)$, ceea ce a permis utilizarea datelor în cadrul studiului.

Figura 1 prezintă exemplul de radiografie de mână şi pumn aparţinând unui subiect participant la studiu. I-a fost atribuit conform metodei lui Fishman stadiul SMI7 (MP5Cap), diafiza falangei mijlocii a degetului 5 fiind înconjurată de epifiză. Figura 2 reprezintă o teleradiografie de profil din lotul studiat marcarea conturului vertebrelor cervicale C2C4. Conform metodei lui Baccetti, i s-a atribuit subiectului stadiul CVMS 3, observându-se prezenţa concavităţilor la nivelul marginii inferioare a vertebrelor C2,C3 şi C4 forma rectangulară a corpului vertebral la nivelul lui C3 C4.

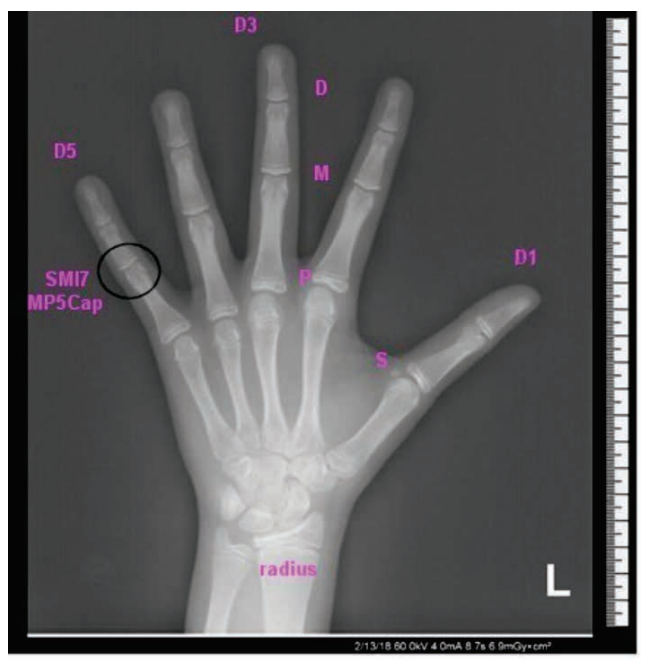

FIGURA 1. Radiografia pumnului (centrii de creștere) 


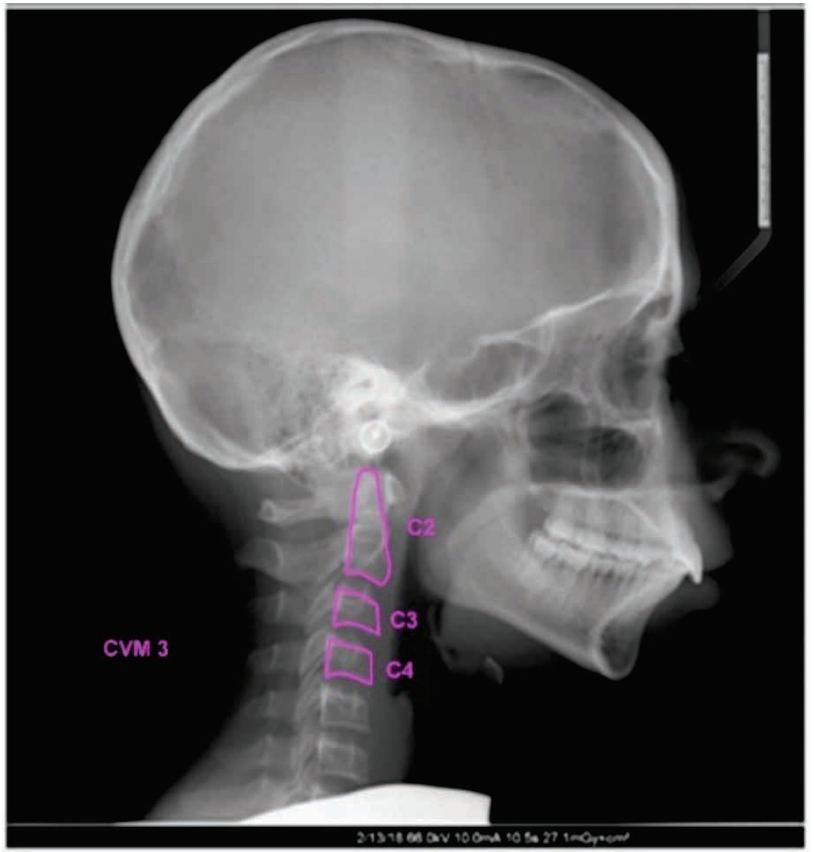

FIGURA 2. Vertebrele cervicale 2,3 și 4

În funçie de sexul subiecţilor, lotul de studiu s-a împărţit pe grupe. Pentru participanţii la studiu din fiecare grupă, s-a determinat vârsta medie la care sunt atinse stadiile SMI CVMS. Pentru fiecare grup în parte, s-a determinat corespondenţa indicilor SMI/CVMS, ţinând cont de vârsta cronologică.

Pentru a verifica statisic corespondenţa între stadiile CVMS şi SMI, s-a folosit un nou parametru, reprezentat de etapele perioadei pubertare, s-a făcut raportarea stadiilor SMI şi CVMS faţă de acestea.

Pentru interpretarea datelor obţinute, au fost efectuate trei analize statistice:

- testul parametric de corelaţie Pearson, pentru a vedea gradul de asociere a valorilor obţinute

- testul t pentru măsurători pereche, pentru a vedea dacă există erori sistematice în cadrul datelor analizate

- coeficientul Cohen kappa (k(,), pentru a determina gradul de concordanţă a indicilor SMI/CVMS în cadrul evaluării etapelor pubertare.

\section{REZULTATE}

Inițial, s-a determinat vârsta medie cronologică la care a fost atins fiecare stadiu SMI şi CVMS, pentru copii şi tinerii din lotul studiat, ţinând cont de dimorfismul sexual (tabelele 3-6).

TABEL 1. Clasificarea stadiilor de osificare conform metodei lui Fishman (1982)

\begin{tabular}{|l|l|l|}
\hline Stadiu & & Modificări la nivelul oaselor \\
\hline 1 & PP3 $=$ & Epifiza falangei proximale a mediusului are aceeași lățime ca și diafiza \\
\hline 2 & MP3 $=$ & Epifiza falangei mijlocii a mediusului are aceeași lățime ca și diafiza \\
\hline 3 & MP5 $=$ & Epifiza falangei mijlocii a degetului cinci are aceeași lățime ca și diafiza \\
\hline 4 & S & Osificarea sesamoidului ulnar \\
\hline 5 & DP3Cap & Diafiza falangei distale a mediusului este înconjurată de epifiză \\
\hline 6 & MP3Cap & Diafiza falangei mijlocii a mediusului este înconjurată de epifiză \\
\hline 7 & MP5Cap & Diafiza falangei mijlocii a degetului cinci este înconjurată de epifiză \\
\hline 8 & DP3U & Fuziunea epifizei și diafizei la nivelul falangei distale a mediusului \\
\hline 9 & PP3U & Fuziunea epifizei și diafizei la nivelul falangei proximale a mediusului \\
\hline 10 & MP3U & Fuziunea epifizei și diafizei la nivelul falangei mijlocii a mediusului \\
\hline 11 & RU & Fuziunea epifizei și diafizei la nivelul radiusului \\
\hline
\end{tabular}

TABEL 2. Stadiile de dezvoltare vertebrală (CVMS) descrise de Baccetti şi colab. (2002)

\begin{tabular}{|l|l|}
\hline $\begin{array}{l}\text { Stadiu } \\
\text { CVMS }\end{array}$ & \multicolumn{1}{c|}{ Descrierea stadiului } \\
\hline CVMS I & $\begin{array}{l}\text { Marginea inferioară a tuturor celor trei vertebre cervicale C2, C3 și C4 este dreaptă sau poate exista o mică concavitate la } \\
\text { nivelul marginii inferioare a lui C2. Marginea superioară a corpului vertebral are formă trapezoidală, fiind înclinat dinspre } \\
\text { posterior spre anterior, Momentul de vârf al creșterii mandibulare nu se va produce mai devreme de } 1 \text { an de la atingerea } \\
\text { acestui stadiu. }\end{array}$ \\
\hline CVMS II & $\begin{array}{l}\text { Se formează concavități la nivelul marginii inferioare a vertebrelor C2 și C3. Corpul vertebrelor C3 și C4 poate fi trapezoidal } \\
\text { sau rectangular orizontală. Momentul de vârf al creșterii mandibulare se va produce după aproximativ } 1 \text { an de la atingerea } \\
\text { acestui stadiu. }\end{array}$ \\
\hline CVMS III & $\begin{array}{l}\text { Se adâncesc concavitățile la nivelul marginii inferioare a vertebrelor C2, C3 și C4. Corpul vertebrelor c3 și c4 are formă } \\
\text { rectangular orizontală. Momentul de vârf al creșterii mandibulare s-a produs cu mai puțin de } 1 \text { an anterior acestui stadiu. }\end{array}$ \\
\hline CVMS IV & $\begin{array}{l}\text { Sunt prezente concavități la nivelul marginii inferioare a vertebrelor C2, C3 și C4 și cel puțin una dintre vertebrele C3 și } \\
\text { C4 are forma pătrată în timp ce cealaltă are formă rectangulară orizontală. Momentul de vârf al creșterii mandibulare s-a } \\
\text { produs cu aproximativ 1 an anterior acestui stadiu. }\end{array}$ \\
\hline CVMS V & $\begin{array}{l}\text { Se adâncesc concavitățile la nivelul marginii inferioare a vertebrelor C2, C3 și C4. Cel puțin una dintre vertebrele C3 și } \\
\text { C4 are corpul rectangular vertical sau are formă pătrată. Momentul de vârf al creșterii mandibulare s-a produs cu } 2 \text { ani } \\
\text { anterior acestui stadiu. }\end{array}$ \\
\hline
\end{tabular}


TABEL 3. Media de vârstă a fiecărui stadiu SMI analizat, pentru fetele din lotul studiat

\begin{tabular}{|l|c|c|c|c|c|c|}
\hline \multicolumn{7}{|c|}{ FETE } \\
\hline \multirow{2}{*}{ Stadiu SMI } & \multirow{2}{*}{ Număr subiecți } & $\begin{array}{c}\text { Procent } \\
\text { \% }\end{array}$ & \multicolumn{4}{|c|}{ Vârstă } \\
\cline { 4 - 7 } & & 19,1 & Media de vârstă (ani) & SD & MIN & MAX \\
\hline 1 (PP2=) & 17 & $\mathbf{8 , 6 8}$ & 0,53 & 8,1 & 9,5 \\
\hline 2 (MP3=) & 14 & 15,7 & $\mathbf{9 , 4 3}$ & 0,96 & 8,1 & 10,8 \\
\hline 3 (MP5=) & 12 & 13,5 & $\mathbf{9 , 6 6}$ & 0,91 & 8,5 & 11,2 \\
\hline 4 (S) & 6 & 6,7 & $\mathbf{9 , 8 3}$ & 0,68 & 8,8 & 10,6 \\
\hline 5 (DP3Cap) & 3 & 3,4 & $\mathbf{1 0 , 9 0}$ & 0,53 & 10,5 & 11,5 \\
\hline 6 (MP3Cap) & 5 & 5,6 & $\mathbf{1 1 , 4 0}$ & 0,85 & 10,2 & 12,4 \\
\hline 7 (MP5Cap) & 12 & 13,5 & $\mathbf{1 1 , 9 8}$ & 0,91 & 10,9 & 13,9 \\
\hline 8 (DP3U) & 4 & 4,5 & $\mathbf{1 3 , 2 0}$ & 1,09 & 11,7 & 14,1 \\
\hline 9 (PP3U) & 3 & 3,4 & $\mathbf{1 4 , 1 0}$ & 0,46 & 13,6 & 14,5 \\
\hline 10 (MP3U) & 11 & 12,4 & $\mathbf{1 4 , 7 9}$ & 1,20 & 13,2 & 17,2 \\
\hline 11 (RU) & 2 & 2,25 & $\mathbf{1 7 , 1 0}$ & 1,27 & 16,2 & 18,0 \\
\hline
\end{tabular}

TABEL 4. Media de vârstă a fiecărui stadiu SMI analizat, pentru băieţii din lotul studiat

\begin{tabular}{|c|c|c|c|c|c|c|}
\hline \multicolumn{7}{|c|}{ BĂIEȚI } \\
\hline \multirow{2}{*}{ Stadiu SMI } & \multirow{2}{*}{$\begin{array}{l}\text { Număr } \\
\text { subiecți }\end{array}$} & \multirow{2}{*}{$\begin{array}{c}\text { Procent } \\
\%\end{array}$} & \multicolumn{4}{|c|}{ Vârstă } \\
\hline & & & Media de vârstă (ani) & SD & MIN & MAX \\
\hline $1(\mathrm{PP} 2=)$ & 13 & 21,3 & 9,48 & 0,65 & 8,7 & 11,0 \\
\hline 2 (MP3=) & 6 & 9,8 & 9,85 & 0,84 & 9,1 & 11,2 \\
\hline 3 (MP5=) & 10 & 16,4 & 11,04 & 0,53 & 10,3 & 12,0 \\
\hline $4(S)$ & 9 & 14,8 & 11,99 & 0,66 & 11,1 & 13,1 \\
\hline 5 (DP3Cap) & 3 & 4,9 & 12,60 & 0,36 & 12,3 & 13 \\
\hline 6 (МР3Сар) & 3 & 4,9 & 12,80 & 0,66 & 12,2 & 13,5 \\
\hline 7 (MP5Cap) & 3 & 4,9 & 12,86 & 0,32 & 12,5 & 13,1 \\
\hline 8 (DP3U) & 2 & 3,3 & 14,80 & 0,14 & 14,7 & 14,9 \\
\hline 9 (PP3U) & 2 & 3,3 & 15,50 & 0,42 & 15,2 & 15,8 \\
\hline 10 (MP3U) & 7 & 11,5 & 15,68 & 1,02 & 14,6 & 17,2 \\
\hline $11(\mathrm{RU})$ & 3 & 4,9 & 15,93 & 0,64 & 15,2 & 16,4 \\
\hline
\end{tabular}

TABEL 5. Media de vârstă a fiecărui stadiu CVMS analizat, pentru fetele din lotul studiat

\begin{tabular}{|l|c|c|c|c|c|c|}
\hline \multicolumn{7}{|c|}{ FETE } \\
\hline \multirow{2}{*}{$\begin{array}{c}\text { STADIU } \\
\text { CVMS }\end{array}$} & $\begin{array}{c}\text { NUMĂR } \\
\text { SUBIECT!I }\end{array}$ & $\begin{array}{c}\text { PROCENT } \\
\text { \% }\end{array}$ & \multicolumn{4}{|c|}{ VÂRSTĂ } \\
\cline { 4 - 7 } & & MEDIA DE VÂRSTĂ(ANI) & SD & MIN & MAX \\
\hline 1 & 27 & 30,3 & $\mathbf{8 , 9 4}$ & 0,79 & 8,1 & 10,4 \\
\hline 2 & 23 & 25,8 & $\mathbf{9 , 8 3}$ & 0,83 & 8,3 & 11,0 \\
\hline 3 & 16 & 18,0 & $\mathbf{1 1 , 4 6}$ & 1,02 & 8,5 & 13,0 \\
\hline 4 & 11 & 12,4 & $\mathbf{1 3 , 2 4}$ & 1,17 & 10,6 & 14,4 \\
\hline 5 & 12 & 13,5 & $\mathbf{1 5 , 3 1}$ & 1,38 & 13,3 & 18 \\
\hline
\end{tabular}

TABEL 6. Media de vârstă a fiecărui stadiu CVMS analizat, pentru băieţii din lotul studiat

\begin{tabular}{|l|c|c|c|c|c|c|}
\hline \multicolumn{7}{|c|}{ BĂIEȚI } \\
\hline STADIU & NUMĂR & PROCENT & \multicolumn{4}{|c|}{ VÂRSTĂ } \\
\cline { 4 - 7 } CVMS & SUBIECTII & $\%$ & MEDIA DE VÂRSTĂ(ANI) & SD & MIN & MAX \\
\hline 1 & 20 & 32,8 & $\mathbf{9 , 8 4}$ & 0,96 & 8,7 & 12,2 \\
\hline 2 & 16 & 26,2 & $\mathbf{1 1 , 5 8}$ & 1,02 & 9,3 & 13,1 \\
\hline 3 & 12 & 19,7 & $\mathbf{1 2 , 3 7}$ & 1,26 & 10,4 & 14,9 \\
\hline 4 & 6 & 9,8 & $\mathbf{1 5 , 5 3}$ & 1,06 & 14,7 & 17,2 \\
\hline 5 & 7 & 11,5 & $\mathbf{1 5 , 7 3}$ & 0,67 & 14,6 & 16,4 \\
\hline
\end{tabular}

Ulterior, s-a încercat găsirea unor corelaţii între indicii SMI şi CVMS, pentru fiecare grup în parte prin suprapunerea vârstelor medii la care apar stadiile SMI CVMS peste axa vârstei cronologice (fig. 3 4). 


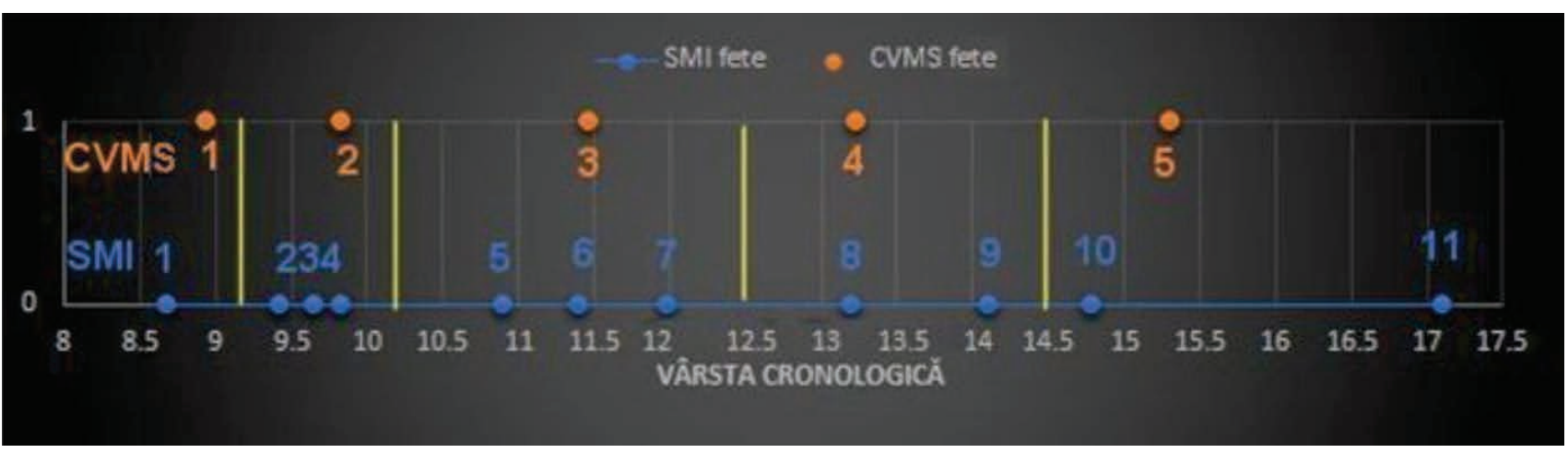

FIGURA 3. Corespondenţa stadiilor CVMS şi SMI pe axa X, reprezentată de vârsta cronologică la fete

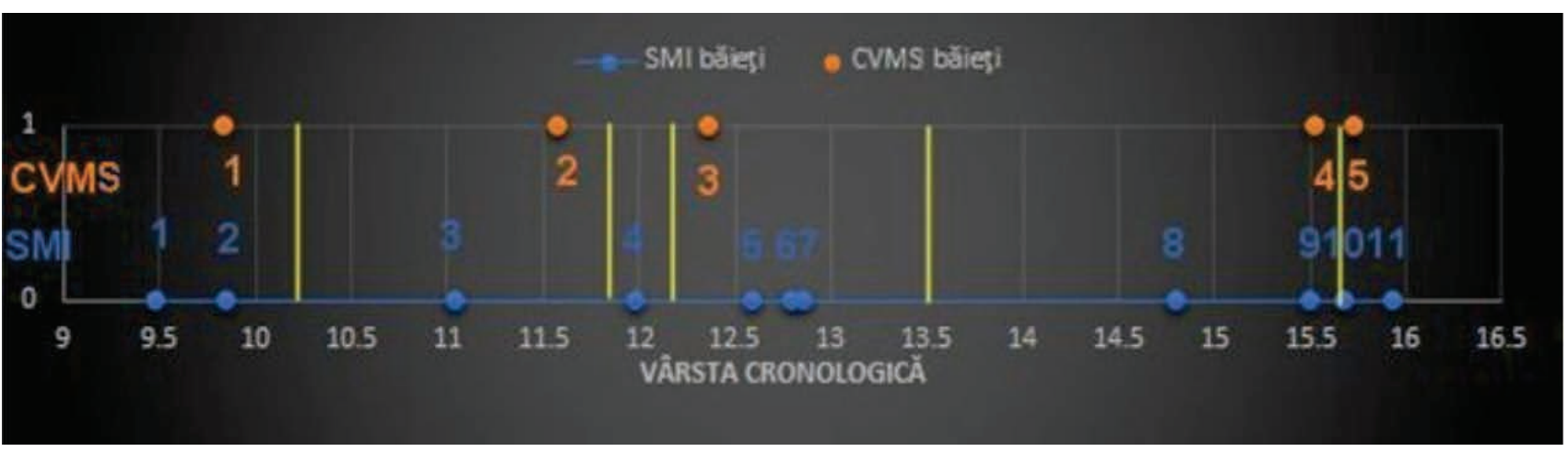

FIGURA 4. Corespondenţa indicilor CVMS şi SMI pe axa X, reprezentată de vârsta cronologică la băieţi

Din analiza graficelor, a fost evidenţiată corespondenţa stadiilor SMI şi CVMS, pentru cele două sexe, plecând de la valorile medii ale vârstelor la care apar aceste stadii (tabel 7).

TABEL 7. Corespondenţa indicilor SMI şi CVMS la fetele băieţii din lotul studiat

\begin{tabular}{|c|c|c|}
\hline Stadiu CVMS & $\begin{array}{c}\text { Corespondență stadiu } \\
\text { SMI fete }\end{array}$ & $\begin{array}{c}\text { Corespondență } \\
\text { stadiu SMI băieți }\end{array}$ \\
\hline CVMS 1 & SMI 1 & SMI 1,2 \\
\hline CVMS 2 & SMI 2,3,4 & SMI 3,4 \\
\hline CVMS 3 & SMI 5,6,7 & SMI 4,5,6, 7 \\
\hline CVMS 4 & SMI 8,9 & SMI 8,9,10 \\
\hline CVMS 5 & SMI 10,11 & SMI 10,11 \\
\hline
\end{tabular}

Se remarcă în cazul lotului de băieţi dificultatea de a găsi un corespondent pentru stadiile SMI 4 şi 10, stadiul SMI 4 fiind întâlnit în stadiile CVMS 2 3, iar stadiul SMI 10 în stadiile CVMS 4 sau 5.

Coroborând datele existente în studiile de specialitate ţinând cont de rezultatele obţinute, am emis următoarea ipoteză:

- etapei prepubertare (faza 1) îi corespund stadiile SMI 1,2,3 şi 4 şi stadiile CVMS 12.

- etapei pubertare, în care găsim momentul de maximă creştere pubertară (faza 2), îi corespund stadiile SMI 5,6 7 stadiul CVMS 3

- etapei postpubertare (faza 3), în care creşterea este diminuată progresiv, până la încheierea ei, îi corespund stadiile SMI 8-11 şi stadiile CVMS 45 (tabel 8).
TABEL 8. Corespondenţa indicilor SMI şi CVMS în funcţie de etapele de creştere şi dezvoltare

\begin{tabular}{|c|c|c|}
\hline Etapă de creștere & SMI & CVMS \\
\hline Etapa prepubertară & $1,2,3,4$ & 1,2 \\
\hline Etapa pubertară & $5,6,7$ & 3 \\
\hline Etapa postpubertară & $8,9,10,11$ & 4,5 \\
\hline
\end{tabular}

Ipoteza emisă s-a verificat statistic cu ajutorul coeficientului Cohen k, după ce s-a realizat conversia în cele 3 faze pentru fiecare stadiu SMI şi CVMS în parte.

La testul parametric de corelaţie Pearson s-au obţinut valori care confirmă existenţa unei corelaţii puternice între datele analizate pentru ambele loturi. Gradul de corelaţie obţinut în cazul fetelor $(\mathrm{r}=$ $0,90)$ a fost mai mare decât în cazul băieţilor ( $r=$ $0,87)$.

Rezultatele testelor t pentru măsurători pereche confirmă absenţa erorilor sistematice. Respectând regula de decizie de la acest tip de test (regula de respingere a ipotezei de nul atunci când $\mathrm{p}$ este sub $5 \%(p=0,05))$ şi ţinând cont de valorile lui $p$ obţinute, $p=0,57$ pentru fete $p=0,76$ pentru băieţi, ipoteza de nul nu se respinge.

Valorile obţinute pentru coeficientul Cohen $\mathrm{k}$ arată existenţa unui acord aproape perfect în cazul fetelor $(\mathrm{k}=0,83)$ şi un acord substanţial în cazul băieţilor $(\mathrm{k}=0,67)$ (tabelele 9 şi 10). 
TABEL 9. Rezultatul coeficientului Cohen k pentru lotul fetelor

\begin{tabular}{|l|r|l|l|r|r|}
\hline & & CVMS & & \\
\hline SMI & $\mathbf{1}$ & $\mathbf{2}$ & $\mathbf{3}$ & TOTAL \\
\hline & 1 & 46 & 2 & 1 & 49 \\
\hline & 2 & 4 & 14 & 2 & 20 \\
\hline & 3 & 0 & 0 & 20 & 20 \\
\hline TOTAL & 50 & 16 & 23 & 89 \\
\hline & & & & \\
\hline$P_{0}$ & 0,8988 & & & \\
\hline$p_{e}$ & 0,407777 & & & \\
\hline$k$ & 0,829118 & acord perfect sau aproape perfect \\
\hline
\end{tabular}

TABEL 10. Rezultatul coeficientului Cohen $k$ pentru lotul băieţilor

\begin{tabular}{|l|r|r|l|r|r|}
\hline & & & CVMS & & \\
\hline SMI & $\mathbf{1}$ & & $\mathbf{2}$ & $\mathbf{3}$ & \multicolumn{2}{|l|}{ TOTAL } \\
\hline & 1 & 32 & 6 & 0 & 38 \\
\hline & 2 & 4 & 5 & 0 & 9 \\
\hline & 3 & 0 & 1 & 13 & 14 \\
\hline TOTAL & 36 & 12 & 13 & 61 \\
\hline & & & & \\
\hline$P_{0}$ & 0,8196 & & & & \\
\hline$p_{e}$ & 0,445579 & & & \\
\hline$k$ & 0,674615 & acord & substanțial & \\
\hline
\end{tabular}

După cum reiese din tabelul 9, în cadrul lotului de fete, 80 dintre cele 89 de evaluări analizate au fost identice, altfel spus, în cadrul lotului de fete, în 80 dintre cele 89 de evaluări analizate, indicii SMI şi CVMS au indicat aceeaşi etapă pubertară. La băieţi, 50 dintre cele 61 de evaluări au fost identice, un număr mai mic comparativ cu lotul fetelor, ceea ce a dus la o valoare mai mică a coeficientului $k$ în cazul băieţilor.

\section{DISCUȚII}

Din analiza datelor a interpretării coeficientului $\mathrm{k}$, se desprind anumite observaţii valabile pentru lotul studiat. Referitor la perioada postpubertară, coeficientul arată un acord aproape perfect. Au fost înregistrate din totalul cazurilor analizate doar un dezacord în lotul băieţilor 3 în cel al fetelor. Ipoteza emisă SMI 8,9,10,11 = CVMS 4,5 se confirmă pentru ambele loturi. Se poate spune că, după momentul de maximă creştere pubertară, corespondenţa indicilor SMI şi CVMS suferă mai puţine variaţii decât în celelalte faze pubertare.

În lotul fetelor, cele mai multe dezacorduri au fost înregistrate la începutul pubertăţii, de cele mai multe ori, indicii SMI confirmând etapa pubertară, în timp ce indicii CVMS indicau spre etapa prepubertară. Prezenţa simultană a indicelui SMI 5 (indi- că etapa pubertară) a stadiului CVMS 2 (indică etapa prepubertară) a dus la acest dezacord. Dezacordul poate fi justificat, întrucât analizând datele din literatură ştim că etapei de maximă creştere pubertară îi pot corespunde stadiile CVMS $23(3,24,25)$. Mai frecvent în cazul fetelor decât al băieţilor, putem întâlni situaţii în care etapei de maximă creştere pubertară îi poate corespunde stadiul CVMS 2, nu doar CVMS 3.

În cazul băieţilor din lotul studiat, cel mai mare dezacord a fost înregistrat tot la începutul pubertăţii, dar, de această dată, indicele CVMS indică spre existenţa etapei pubertare, iar indicele SMI spre etapa prepubertară. Această informaţie poate fi analizată în două moduri: fie în unele cazuri stadiul SMI 4 apare în timpul momentului de maximă creştere pubertară (fapt susţinut şi de studiul lui Grave Brown, 1976 (2), care găsesc perioada de maximă creştere pubertară corespondentă stadiilor SMI 45 la băieţi); fie în unele cazuri, existenţa stadiului CVMS 4 ar aparţine perioadei de maximă creştere pubertară şi nu etapei postpubertare.

În cazul băieţilor din lotul studiat, stadiul CVMS 2 poate fi întâlnit şi în etapa pubertară, nu doar în cea prepubertară. Din cauza variabilităţii mari a vârstei cronologice în atingerea stadiilor SMI şi CVMS şi a variabilităţii individuale în ceea ce priveşte etapele perioadei pubertare, rezultatele acestui studiu trebuie privite cu prudenţă când dorim să evaluăm concret momentul biologic în care se găseşte pacientul. Scopul acestui studiu a fost să arate corelaţia existentă între indicii SMI şi CVMS şi să dovedească statistic corespondenţa stadiilor SMI şi CVMS, ceea ce ar face posibilă în practică folosirea teleradiografiei de profil pentru estimarea momentului de creştere în care se află pacientul.

Limitările studiului vin din faptul că mediile de vârstă la care sunt atinse stadiile SMI CVMS, folosite pentru emiterea ipotezei studiului au fost obţinute în urma unui studiu transversal, care prezintă un instantaneu, surprins la un moment dat. Pentru o relevanţă superioară, considerăm utilă realizarea unui studiu longitudinal. Acesta este motivul pentru care rezultatele acestui studiu trebuie privite interpretate cu prudenţă.

$\mathrm{O}$ altă limitare vine din numărul mic de participanţi la acest studiu şi din lipsa de omogenitate a lotului în ceea ce priveşte numărul de participanţi pe grupe de vârstă, numărul mic fiind justificat de necesitatea actuală de a limita doza de radiaţii la care supunem pacienţii.

\section{CONCLUZII}

Cercetarea realizată confirmă corelaţia puternică existentă între indicii SMI şi CVMS. Gradul de corelaţie obţinut în cazul fetelor $(r=0,90)$ este mai mare decât în cazul băieţilor $(r=0,87)$. 
S-a obţinut un acord aproape perfect în cazul fetelor $(\mathrm{k}=0,83)$ şi un acord bun în cazul băieţilor $(\mathrm{k}=$ 0,67). Cel mai probabil, această diferenţă înregistrată în lotul băieţilor se datorează variaţiei de corespondenţă a stadiului SMI 4 cu stadiul CVMS 2 sau 3, stadiul SMI 4 putând fi întâlnit fie spre sfârşitul perioadei prepubertare, fie la debutul perioadei pubertare.

Cercetarea realizată confirmă variabilitatea mare a vârstei cronologice în atingerea stadiilor SMI şi CVMS şi dovedeşte variabilitatea individuală în ceea ce priveşte parcurgerea etapelor pubertare.
Aceasta obligă la prudenţă în interpretarea rezultatelor obţinute în acest studiu transversal.

Corespondenţa dovedită statistic între stadiile SMI CVMS validează folosirea în practica curentă a teleradiografiei de profil pentru estimarea momentului de creştere în care se află pacientul, evitând astfel expunerea pacientului la o iradiere suplimentară, necesară pentru realizarea radiografiei de mână.

\section{Notă}

Toți autorii au contribuții egale.

Conflict of interest: none declared Financial support: none declared

\section{BIBLIOGRAFIE}

1. Gupta M, Divyashree R, Abhilash P, A Bijle MN, Murali K. Correlation between Chronological Age, Dental Age and Skeletal Age among Monozygoyic and Dizygotic Twins. J Int Oral Health. 2013 Feb; 5(1):16-22.

2. Grave KC, Brown T. Skeletal ossification and the adolescent growth spurt. Am J Orthod. 1976 Jun;69(6):611-9.

3. Grave B, Brown T, Townsend G. Comparison of cervicovertebral dimensions Australian Aborigines and Caucasians. Eur J Orthod. 1999 Apr;21(2):127-35.

4. Fishman LS. Chronological versus skeletal age, an evaluation of craniofacial growth. Angle Orthod. 1979 Jul;49(3):181-9.

5. Fishman LS. Maturational patterns and prediction during adolescence. Angle Orthod. 1987 Jul;57(3):178-93.

6. Turchetta BJ, Fishman LS, Subtelny JD. Facial growth prediction: a comparison of methodologies. Am J Orthod Dentofacial Orthop. 2007 Oct;132(4):439-49.

7. Baccetti T, Franchi L, McNamara JA Jr. An improved version of the cervical vertebral maturation (CVM) method for the assessment of mandibular growth. Angle Orthod. 2002 Aug;72(4):316-23.

8. Hassel B, Farman AG. Skeletal maturation evaluation using cervical vertebrae. Am J Orthod Dentofacial Orthop. 1995 Jan;107(1):58-66.

9. Hägg U, Taranger J. Menarche and voice change as indicators of the pubertal growth spurt. Acta Odontol Scand. 1980;38(3):179-86.

10. Hägg U, Taranger J. Skeletal stages of the hand and wrist as indicators of the pubertal growth spurt. Acta Odontol Scand. 1980; 38(3):187-200.

11. Kopecky GR, Fishman LS. Timing of cervical headgear treatment based on skeletal maturation. Am J Orthod Dentofacial Orthop. 1993 Aug;104(2):162-9.

12. Baccetti T, Franchi L, Kim LH. Effect of timing on the outcomes of 1-phase nonextraction therapy of Class II malocclusion. Am J Orthod Dentofacial Orthop. 2009 Oct;136(4):501-9.

13. García-Fernandez P, Torre H, Flores L, Rea J. The cervical vertebrae as maturational indicators. J Clin Orthod. 1998 Apr;32(4):221-5.

14. O'Reilly MT, Yanniello GJ. Mandibular growth changes and maturation of cervical vertebrae--a longitudinal cephalometric study. Angle Orthod. 1988 Apr;58(2):179-84.
15. Kucukkeles N, Acar A, Biren S, Arun T. Comparisons between cervical vertebrae and hand-wrist maturation for the assessment of skeletal maturity. J Clin Pediatr Dent. 1999 Fall;24(1):47-52.

16. Franchi L, Baccetti T, McNamara JA Jr. Mandibular growth as related to cervical vertebral maturation and body height. Am J Orthod Dentofacial Orthop. 2000 Sep;118(3):335-40. treatment timing for maxillary expansion and protraction therapy followed by fixed appliances. Am J Orthod Dentofacial Orthop. 2004 Nov;126(5):555-68.

18. Chang HP, Liao CH, Yang YH, Chang HF, Chen KC. Correlation of cervical vertebra maturation with hand-wrist maturation children. Kaohsiung J Med Sci. 2001 Jan;17(1):29-35.

19. San Román P, Palma JC, Oteo MD, Nevado E. Skeletal maturation determined by cervical vertebrae development. Eur J Orthod. 2002 Jun;24(3):303-11.

20. Ballrick J, Fields H, Vig K, Beck FM, et al. Reliability and Validity of Cervical Vertebral Maturation and Hand-Wrist Radiographs. Available at: https://iadr.abstractarchives.com/abstract/2005Balt-62129/ reliability-and-validity-of-cervical-vertebral-maturation-and-handwrist-radiographs.

21. Flores-Mir C, Burgess CA, Champney M, Jensen RJ, Pitcher MR, Major PW. Correlation of skeletal maturation stages determined by cervical vertebrae and hand-wrist evaluations. Angle Orthod. 2006 Jan;76(1):1-5.

22. Manosudprasit M, Wangsrimongkol T, Pisek P, Chantaramungkorn M. Comparative study between the hand-wrist method and cervical vertebral maturation method for evaluation skeletal maturity cleft patients. J Med Assoc Thai. 2013 Sep;96 Suppl 4:S19-24.

23. Fishman LS. Radiographic evaluation of skeletal maturation. A clinically oriented method based on hand-wrist films. Angle Orthod. $1982 \mathrm{Apr} ; 52(2): 88-112$.

24. Grave K, Townsend G. Cervical vertebral maturation as a predictor of the adolescent growth spurt. Aust Orthod J. 2003 Apr;19(1):25-32.

25. Grave K, Townsend G. Hand-wrist and cervical vertebral maturation indicators: how can these events be used to time Class II treatments? Aust Orthod J. 2003 Nov;19(2):33-45.
17. Franchi L, Baccetti T, McNamara JA. Postpubertal assessment of 